\title{
Effect of protein and methionine levels in a semi- organic diet for dual-purpose type chickens on slaughter performance and nitrogen balance*
}

\author{
J. Koreleski ${ }^{1}$ and S. Świątkiewicz \\ Research Institute of Animal Production, \\ Department of Animal Nutrition and Feed Science \\ 32-083 Balice, Poland
}

(Received 13 February 2008; revised version 26 May 2008; accepted 24 June 2008)

\begin{abstract}
In a model experiment, dual-purpose type chickens (Barret Rock $\times$ New Hampshire) were allocated to 4 groups with 5 replications of 4 males and 4 females. For the first (1-49 days) and second (50-83 days of age) period of feeding, the chickens were fed diets composed of feeds approved for organic production. The diets for both periods contained lower (20 and 18\%) or higher (22 and $19 \%$ ) levels of crude protein, 0.36 and $0.25 \%$ or 0.38 and $0.28 \%$ of total methionine, and 0.66 and $0.57 \%$ or 0.70 and $0.61 \%$ sulphur amino acids, respectively. Diets were supplemented or not with DL-methionine (Met). In the last week of each period, feed intake was determined, excreta were collected for N-balance calculation. Body weight gain, feed intake, feed conversion and mortality were estimated and production index values calculated. On day 83 of life, 4 males and 4 females were killed and slaughter analysis was performed.

The higher dietary crude protein level increased feed intake and worsened feed conversion in the first and second period of feeding and increased feed intake for the whole experiment. Met supplemented to the diets positively affected body weight gain, feed conversion and production index in the second and entire feeding period. It also increased breast meat yield and decreased abdominal fat content in carcass. Increased $\mathrm{N}$-excretion and $\mathrm{N}$-retention at the higher level of dietary crude protein and the positive effect of Met supplementation on nitrogen utilization did not reach statistical significance $(\mathrm{P}>0.05)$. Nevertheless, for the whole period of feeding, Met added to the diet reduced nitrogen pollution of the environment from dual-purpose type chickens for a total 4.7 to $4.9 \mathrm{~g} / \mathrm{chick} / 83$ days.
\end{abstract}

KEY WORDS: dual purpose type chickens, protein level, methionine supplementation, N-balance, carcass quality

\footnotetext{
${ }^{*}$ Supported by Statutory Activity, Project No. 2246.1

${ }^{1}$ Corresponding author: e-mail: jkoreles@izoo.krakow.pl
} 


\section{INTRODUCTION}

The formulation of protein- and amino acid-balanced diets for broiler chickens without synthetic amino acid supplementation is limited because of relatively high requirements (Mack et al., 1999). A low supply of methionine may be compensated by increasing the content of dietary crude protein. Earlier papers suggest that higher levels of poor quality protein will result in nearly as good growth as can be obtained with practical diets containing balanced protein (Carpenter and de Muelenaere, 1965). Wethli et al. (1975) reported, however, that the poor quality of a protein source could not always be offset by increasing the concentration of dietary protein because of amino acid disproportion and impaired utilization of limiting amino acids. Only when deficiencies are corrected with added limiting amino acids control and experimental diets support the same growth rate in chickens (Wethli et al., 1975).

Feeds of plant origin approved for ecological poultry production according to EC Regulations (2092/91, Anex I B 4.2-4.3, Anex II C, 1804/99 and 834/2007) mention lysine-rich protein sources, but they are relatively poor in sulphur amino acids (SAA). The use of racemic, crystalline DL-methionine (Met) in organic production is controversial: it is prohibited in Europe and under discussion in the United States (Moritz et al., 2005). Addition of synthetic Met enables elimination of excess protein in the diet to cover SAA requirements of fast- and slow-growing broiler chickens (Lewis et al., 1997; Lemme et al., 2005). An optimum level of SAA in feed for chickens may depend on the dietary protein level (Vieira et al., 2004).

It is well known that a surplus of lysine and other amino acids in the diet is metabolized to uric acid and may affect the amount of nitrogen excreted into the environment. Lemme et al. (2005) reported impaired nitrogen utilization in ISA J 257 slow-growing broiler chickens fed from days 1 to 69 of age with an organic diet not supplemented with Met.

Because the proportion of SAA to lysine in organic diets is generally low, the supplementation of limiting amino acids could improve performance and decrease $\mathrm{N}$ excretion in broiler chickens. As opposed to fast-growing or slowgrowing broiler chickens fed and kept up to 10 weeks of age (Waldroup et al., 2001; Havenstein et al., 2003a,b), in dual-purpose type chickens kept for longer than 81 days (according to EC Regulations) the effect of methionine and protein level in the organic diet on nitrogen excretion is not well known.

In this paper, the performance, slaughter indices and nitrogen utilization in dual-purpose chickens were evaluated in response to different dietary protein levels and methionine supplementation during 83 days of feeding. Dual-purpose hybrid chickens were used in the experiment because they need a longer time $(>81$ days) to achieve slaughter maturity than slow-growing broilers. 


\section{MATERIAL AND METHODS}

The trial was conducted from 1 to 83 days of age with 160 dual-purpose hybrid chickens ( ${ }^{\lambda}$ Barret Rock $\times$ New Hampshire) allocated to 4 groups in 5 replicates, each containing 4 males and 4 females. The average initial body weight of chicks was $39 \mathrm{~g}$. The birds were kept in wire-floor cages to allow excreta collection and were nonpastured. For first (1-49 days) and the second (50-83 days of age) periods of feeding, the basal semi-organic diets contained a lower (group I) or higher (group II) content of crude protein (Table 1). The feed components used are on the list recommended for organic feeding but were not, however, certified organic. Grain-based diets, fed as mash, contained soya seed, pea seeds, dried milk and fish meal as the major protein sources.

Soyabean seeds were toasted to deactivate anti-proteolytic factor and contained urease activity $<0.4 \mathrm{mg} \mathrm{N} / \mathrm{g} / \mathrm{min}$.

Table 1. Composition of basal diets, $\mathrm{g}^{\cdot} \mathrm{kg}^{-1}$

\begin{tabular}{|c|c|c|c|c|}
\hline \multirow{3}{*}{ Item } & \multicolumn{2}{|c|}{ Lower crude protein } & \multicolumn{2}{|c|}{ Higher crude protein } \\
\hline & \multicolumn{4}{|c|}{ period of feeding, days } \\
\hline & $1-49$ & $50-83$ & $1-49$ & $50-83$ \\
\hline \multicolumn{5}{|l|}{ Compositions } \\
\hline wheat & 55.10 & 52.15 & 47.80 & 43.25 \\
\hline barley & 6.0 & 8.0 & 6.0 & 7.0 \\
\hline soyabean seeds & 12.0 & 17.0 & 16.0 & 22.5 \\
\hline pea seed & 12.0 & 15.5 & 14.0 & 18.5 \\
\hline dried skimmed milk & 6.0 & 4.0 & 6.0 & 5.5 \\
\hline fish meal & 6.5 & & 6.0 & \\
\hline limestone & 1.2 & 1.25 & 1.15 & 1.25 \\
\hline dicalcium phosphate & 0.55 & 0.40 & 0.40 & 1.30 \\
\hline $\mathrm{NaCl}$ & 0.15 & 0.30 & 0.15 & 0.30 \\
\hline vitamin-mineral premix $^{1}$ & 0.5 & 0.5 & 0.5 & 0.5 \\
\hline \multicolumn{5}{|l|}{ Nutrients content } \\
\hline crude protein, analysed & 207 & 177 & 219 & 186 \\
\hline $\mathrm{ME}, \mathrm{MJ} \cdot \mathrm{kg}^{-1,2}$ & 12.05 & 12.1 & 12.05 & 12.1 \\
\hline Lys, analysed & 11.9 & 9.0 & 13.1 & 10.6 \\
\hline Met, analysed & 3.59 & 2.55 & 3.77 & 2.80 \\
\hline Met + Cys, analysed & 6.65 & 5.66 & 7.03 & 6.06 \\
\hline $\mathrm{Ca}^{3}$ & 9.2 & 8.95 & 9.2 & 8.95 \\
\hline $\mathrm{P}_{\text {available }}{ }^{3}$ & 4.2 & 3.95 & 4.2 & 3.95 \\
\hline
\end{tabular}

${ }^{1}$ contained no antioxidants, coccidiostatics and growth promotors; supplied to $1 \mathrm{~kg}$ of diet: from 1 to 49 days of age: IU: vit. A 10500; $\mathrm{D}_{3} 2500 ; \mathrm{mg}$ : vit. $\mathrm{E} 40 ; \mathrm{K}_{3} 2 ; \mathrm{B}_{1} 1.5 ; \mathrm{B}_{2} 5.5 ; \mathrm{B}_{6} 3.25 ; \mathrm{B}_{12} 0.025$; biotin 0.1; Ca-pantothenate 12; niacin 35; folic acid 1.0; choline- $\mathrm{HCl} 400 ; \mathrm{Mn} \mathrm{80;} \mathrm{Zn} \mathrm{50;} \mathrm{Fe} \mathrm{60;}$ $\mathrm{Cu} 8$; J 0.8; Se 0.2 and Co 0.4; from 50 to 83 days of age: IU: vit. A 8400; D 2000; mg: vit. E 32; $\mathrm{K}_{3}$ 1.6; $\mathrm{B}_{1} 1.2 ; \mathrm{B}_{2} 4.4 ; \mathrm{B}_{6} 2.6 ; \mathrm{B}_{12} 0.02$; biotin 0.08; Ca-pantotenate 9.6; niacin 28; folic acid 0.8; choline-HCl 320; Mn 64; Zn 40; Fe 48; Cu 6.4; J 0.64; Se 0.16 and Co 0.32

2 calculated according to European Table of Energy Values for Poultry Feedstuffs (1989) as a sum of $\mathrm{ME}$ content of feed components; ${ }^{3}$ calculated from tables of feed composition 
The nutrient content of the lower protein basal diet (group I) was formulated according to requirements for broiler breeder chickens (Smulikowska and Rutkowski, 2005) taking into account organic production limitations for the choice of feed components, vitamins and trace-elements (Table 1). In the higher protein basal diet, the contribution of protein sources was increased. The dietary methionine and SAA content in both basal diets was relatively low and experimental diets were supplemented $\left(\mathrm{g} \cdot \mathrm{kg}^{-1}\right)$ with 0.4 or $0.3 \mathrm{~g}$ DL-methionine (Met), $98 \%$, Degussa in the consecutive periods of feeding, respectively. Met supplementation increased the dietary total methionine level to 0.40 or $0.28 \%$ in the lower- and to 0.42 or $0.31 \%$ in the higher-protein diets. Body weight (BW), feed intake (FI) and mortality were measured and body weight gain (BWG) and feed conversion ratio (FCR) were calculated for the first, second and entire feeding period. On the basis of final BWG, FCR and mortality, the efficiency of performance index (EPI) was calculated for each experimental group.

In the $6^{\text {th }}$ and $11^{\text {th }}$ weeks of age, feed intake was measured for 5 days and total collection of excreta from each replicate was carried out in all groups. Excreta were pooled, weighed and stored at $-20^{\circ} \mathrm{C}$. After thawing, the excreta were weighed again, homogenized and representative samples were analysed for $\mathrm{N}$ and dry matter content. Nitrogen content in diets and in excreta were estimated by the Kjeldahl method (AOAC, 1990) using a Kjeltec Auto 1030, Tecator. Nbalance indices were calculated from $\mathrm{N}$ ingested and $\mathrm{N}$ excreted. The amino acid content of diets was analysed in acid hydrolysates as the colour reaction with the ninhydrin reagent, using a Beckman-System Gold 126 AA automatic analyser. SAA were estimated after preoxidation to sulphone.

At the end of the experiment and after $12 \mathrm{~h}$ of starvation, 4 representative cockerels and 4 hens were chosen from each group and decapitated. The mass of cooled carcasses and edible giblets was estimated and carcass, breast meat, leg and abdominal fat yields were calculated (Ziołecki and Doruchowski, 1989).

Data were subjected to two-way factorial analysis of variance. Differences were considered significant at $\mathrm{P} \leq 0.05$. All statistical analyses were performed with Statistica 5.0 PL software (Statsoft Inc.).

\section{RESULTS}

The performance of chickens in the first period of feeding was negatively affected when they were fed the higher-protein diets (Table 2). The higher level of dietary protein increased FI and worsened FCR $(\mathrm{P} \leq 0.05)$. Met addition had no effect on performance parameters. 
Table 2. Effect of methionine addition and crude protein level in the diet on performance indices

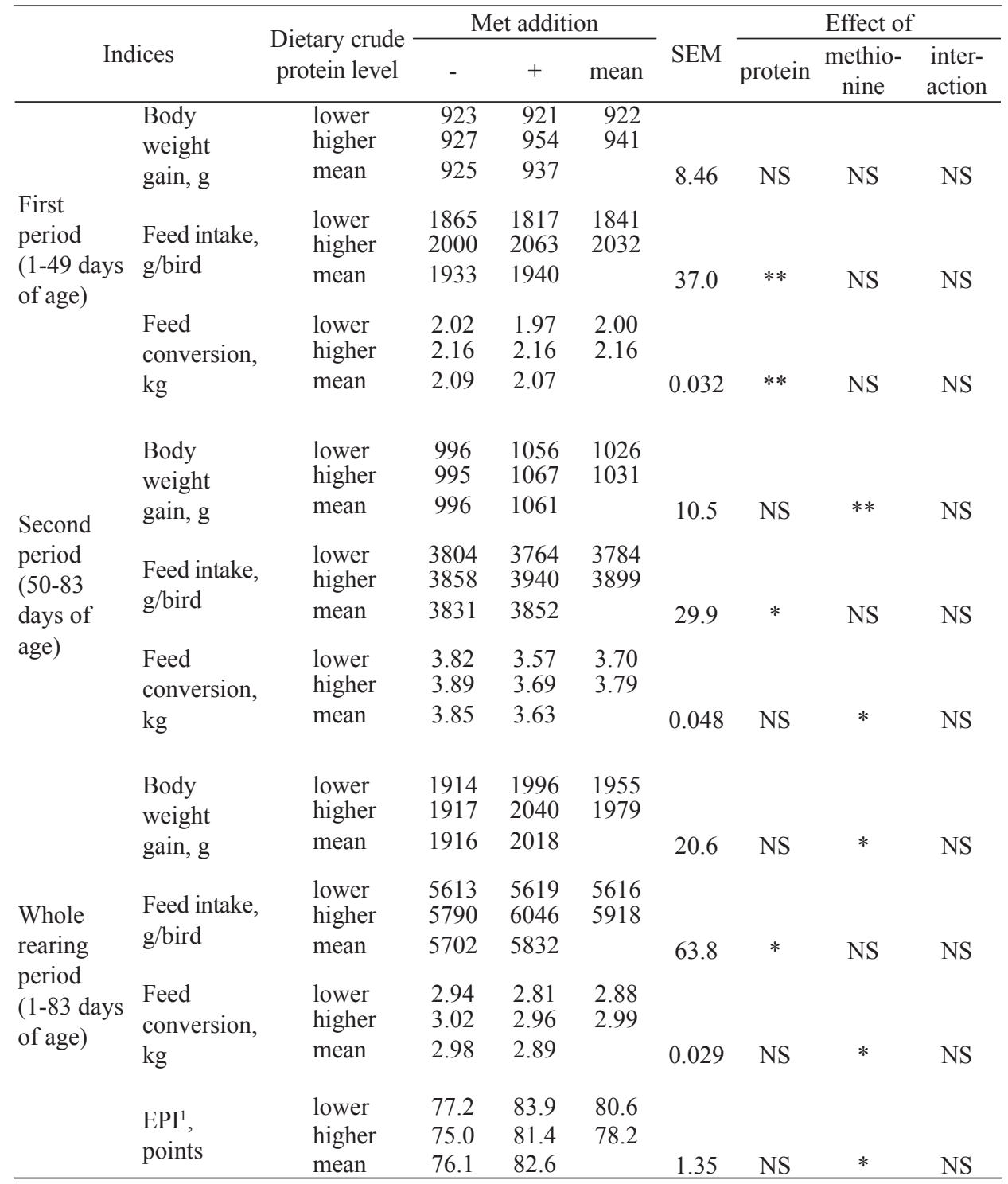

${ }^{1}$ efficiency of performance index; NS - $\mathrm{P}>0.05, * \mathrm{P} \leq 0.05, * * \mathrm{P} \leq 0.01$

In the second period of feeding, the higher dietary protein level also increased FI, whereas Met supplementation improved $(\mathrm{P} \leq 0.05)$ BWG and FCR (Table $2)$. For the whole rearing period (1-83 days of age) the effect was statistically confirmed for dietary protein level and for added Met $(\mathrm{P} \leq 0.05)$. Higher dietary 
protein increased FI, whereas the Met supplement increased BWG and positively affected FCR and EPI.

Addition of Met also had a beneficial effect on some results of slaughter analysis (Table 3). In chickens fed diets with a higher methionine level, the

Table 3. Effect of methionine addition and crude protein level on results of slaughter analysis

\begin{tabular}{|c|c|c|c|c|c|c|c|c|}
\hline \multirow[b]{2}{*}{ Indices } & \multirow{2}{*}{$\begin{array}{l}\text { Dietary crude } \\
\text { protein level }\end{array}$} & \multicolumn{3}{|c|}{ Met addition } & \multirow[b]{2}{*}{ SEM } & \multicolumn{3}{|c|}{ Effect of } \\
\hline & & - & + & mean & & protein & $\begin{array}{l}\text { methio- } \\
\text { nine }\end{array}$ & $\begin{array}{l}\text { inter- } \\
\text { action }\end{array}$ \\
\hline \multirow{3}{*}{$\begin{array}{l}\text { Carcass yield, } \\
\%\end{array}$} & lower & 72.3 & 72.9 & 72.6 & & & & \\
\hline & higher & 72.9 & 72.2 & 72.5 & & & & \\
\hline & mean & 72.6 & 72.5 & & 0.205 & NS & NS & NS \\
\hline \multirow{3}{*}{$\begin{array}{l}\text { Breast meat } \\
\text { yield, } \\
\% \text { of carcass }\end{array}$} & lower & 15.4 & 16.3 & 15.9 & & & & \\
\hline & higher & 15.3 & 16.0 & 15.7 & & & & \\
\hline & mean & 15.4 & 16.2 & & 0.203 & NS & $*$ & NS \\
\hline \multirow{3}{*}{$\begin{array}{l}\text { Leg yield, } \\
\% \text { of carcass }\end{array}$} & lower & 32.3 & 34.4 & 33.4 & & & & \\
\hline & higher & 33.6 & 33.6 & 33.6 & & & & \\
\hline & mean & 33.0 & 34.0 & & 0.409 & NS & NS & NS \\
\hline \multirow{3}{*}{$\begin{array}{l}\text { Abdominal fat } \\
\text { content, } \\
\% \text { of carcass }\end{array}$} & lower & 2.94 & 1.78 & 2.36 & & & & \\
\hline & higher & 2.65 & 2.50 & 2.57 & & & & \\
\hline & mean & 2.79 & 2.14 & & 0.156 & NS & $*$ & NS \\
\hline \multirow{3}{*}{$\begin{array}{l}\text { Relative weight } \\
\text { of liver, } \\
\% \text { of carcass }\end{array}$} & lower & 1.96 & 1.98 & 1.97 & & & & \\
\hline & higher & 1.97 & 1.89 & 1.93 & & & & \\
\hline & mean & 1.97 & 1.93 & & 0.025 & NS & NS & NS \\
\hline \multirow{3}{*}{$\begin{array}{l}\text { Relative weight } \\
\text { of gizzard, } \\
\% \text { of carcass }\end{array}$} & lower & 2.03 & 2.25 & 2.14 & & & & \\
\hline & higher & 2.20 & 2.11 & 2.15 & & & & \\
\hline & mean & 2.11 & 2.18 & & 0.053 & NS & NS & NS \\
\hline
\end{tabular}

breast meat yield and lower abdominal fat content in carcasses was bigger and lower, respectively, than on unsupplemented diets.

The effect of dietary protein and methionine levels on nitrogen balance (Table 4 ) in the first and second periods of feeding did not reach statistical significance $(\mathrm{P}>0.05)$. In both periods of feeding, numerical tendencies towards increased nitrogen retention in chickens at higher protein levels and for decreased nitrogen excretion and increased nitrogen retention at the higher methionine level in the diet were observed. 
Table 4. Effect of methionine addition and crude protein level in the diet on nitrogen balance

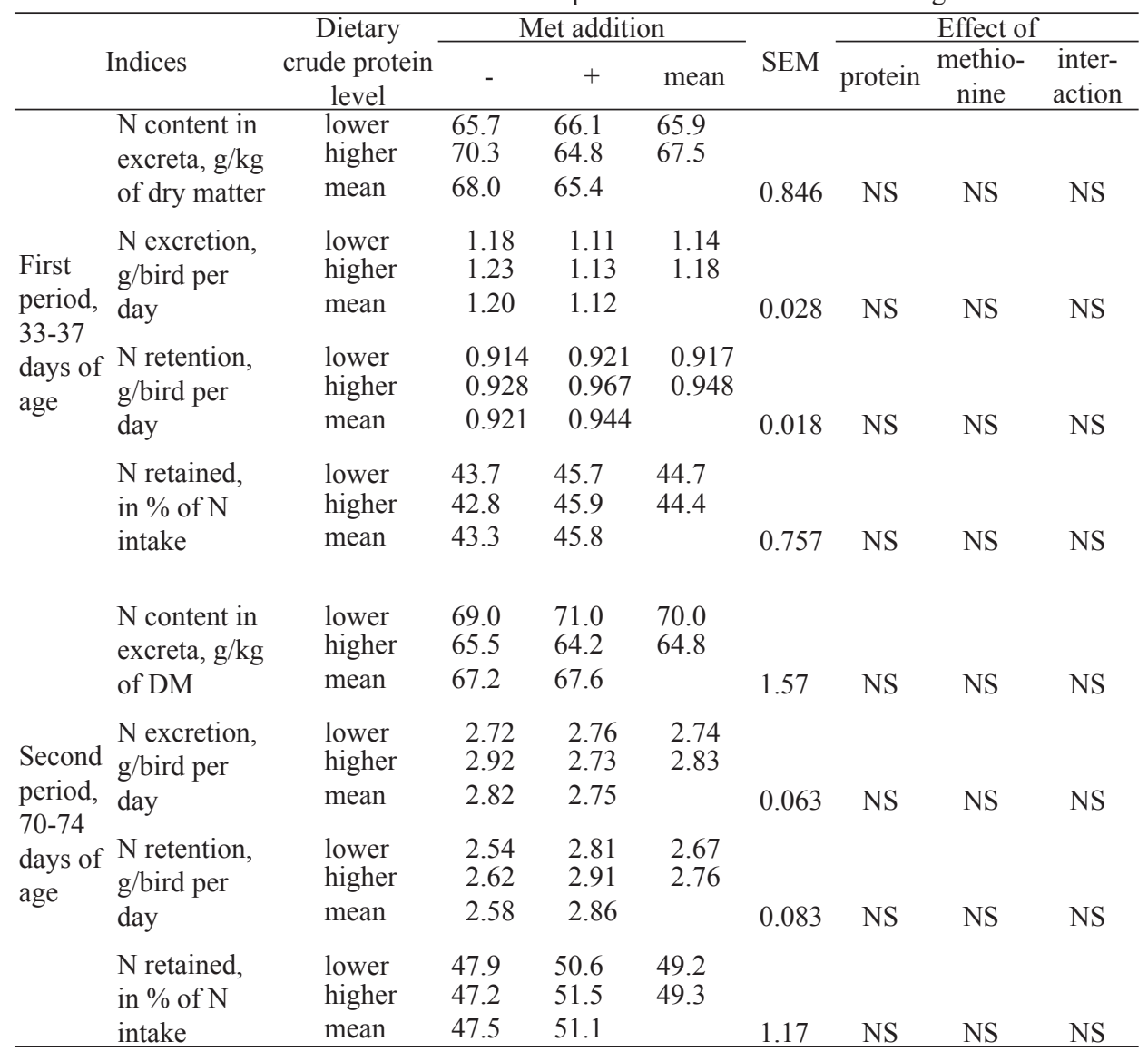

NS - P $>0.05$

\section{DISCUSSION}

In the current study, in the first period of feeding, the ratio of dietary methionine to lysine (Met:Lys) in the basal diet with a lower or higher protein content was 30.2 or 28.8 , and SAA:Lys 55.9 and 53.7, respectively. Met supplementation increased the methionine content to 0.40 and $0.42 \%$ and Met:Lys ratio to 33.5 or 31.8 in the lower- and higher-protein diets, respectively. In the same way the SAA:Lys ratio increased to 59.2 and 56.7 .

The dietary methionine level in the basal diets was close to the Label Rouge type of diets cited by Lewis et al. (1997). It was lower, however, than for slow growing broiler chickens ( $0.48 \%$ Met; Met:Lys=35.3) in diets used by Lewis et al. (1997) and 
lower than $0.43 \%$ Met; Met:Lys=37.4 in the experiment by Lemme et al. (2005). As compared with nutrient requirements for lay-type Leghorn chickens $(0.30 \%$ Met; Met:Lys $=35.3$; NRC, 1994) the basal diet for the first period of feeding contained a comparable content of $\mathrm{ME}_{\mathrm{N}}$ but higher levels of protein, Lys and Met.

In the present study, at the end of the $6^{\text {th }}$ week (49 days) of age, the provided diets supported, on average, $970 \mathrm{~g} \mathrm{BW}$ in chickens. The higher level of crude protein in the diet did not improve BWG but increased FI and, as a consequence, worsened FCR. Since Met supplementation did not affect the performance indices, this may suggest that in the first period of feeding, methionine and protein requirements of dual-purpose type chickens were satisfied by the lower protein diet.

In the second period of feeding (50-83 days of age), the ratio of dietary Met: Lys in the basal diet with a lower or higher protein content was 28.3 and 26.4, and SAA:Lys was 62.9 and 57.2, respectively. Metionine supplementation to the diet increased the Met:Lys ratio to 31.7 and 29.2, the SAA:Lys ratio to 66.2 and 60.0 in the lower and higher protein diets, respectively. The methionine content in the basal diets was comparable to $0.29 \%$ Met; Met:Lys $=32.9$ in the Label Rouge diet but was lower than $0.41 \%$ Met; Met:Lys=39.05 for slow-growing broiler chickens in the experiment of Lewis et al. (1997) and lower than $0.38 \%$ Met; Met:Lys $=38.0$ used by Lemme et al. (2005). In the current study, the methionine content of $0.25 \%$ in the basal diet for chickens at 50-83 days of age was close to requirements $(0.25 \%)$ of lay-type Leghorn chickens, but the Met:Lys ratio lower than 41.7 (NRC, 1994).

The experimental diets supported chickens with an average $2006 \mathrm{~g}$ final body weight at 12 weeks of age. Similarly as in the first period of feeding, the higher dietary protein level increased FI without a significant effect on other performance indices. Improved BWG and FCR found in chickens fed diets supplemented with Met may indicate methionine deficiency in the basal diet for growth in the second period of feeding. That deficiency was not covered by the higher protein level in the diet, probably because the Met:Lys proportion was not corrected simultaneously.

In the current study, throughout the entire period of feeding the higher-protein diet FI was increased, but other performance indices were not significantly changed. The results of this experiment are generally in agreement with those reported by Carpenter and Muelenaere (1965) and, in part, with the results of Vieira et al. (2004) and Quentin et al. (2005). For faster growth in chickens, however, a supplement of methionine was effective and amino acid addition also improved FCR and EPI values. A positive effect of Met supplementation to the organic diet on BWG, FI and FCR for some periods of age was reported for slowgrowing broilers by Lemme et al. (2005).

It is not unlikely that the negative effect of an increased protein level in the current study was a result of lysine excess in the diet for first and the second period 
of feeding. The diet with the higher protein level had a lower calculated Met:Lys ratio. Met supplementation increased the level of methionine in the diet and its proportion to lysine.

At the end of the presented experiment the slaughter indices changed only when Met had been supplemented to the diet. In chickens fed supplemented diets, higher breast meat yield and reduced abdominal fat content were found. Lemme et al. (2005) and Moritz et al. (2005) found a non-significant effect of Met supplementation on breast meat yield in the carcass of slow-growing broilers. However in the experiment of Vieira et al. (2004), increased SAA levels in the diet resulted in dose-response enlargement of breast meat yield and in a decrease of the proportion of abdominal fat in the carcass. A higher level of protein in the diet did not, however, alter carcass composition, and this result supports the results of Quentin et al. (2003).

In the presented paper the effect of higher dietary protein or methionine supplementation on N-balance was not significant in either period of feeding, but numerical differences could be seen. In both periods of feeding, increasing dietary protein had a tendency to increase nitrogen excretion and nitrogen retention in the chicken body, but nitrogen utilization was not changed. The opposite tendency was observed as a result of adding Met to the diet. Amino acid supplementation numerically decreased nitrogen excretion in excreta and enlarged N-retention and nitrogen utilization. A significant effect of methionine supplementation on nitrogen utilization in the period of 1-69 days of feeding (25.4 vs 33.50\%) was reported, however Lemme et al. (2005) used slowly growing broiler chickens.

The influence of Met supplementation to the diet for dual-purpose type chickens in the reported experiment is not as distinct and significant as in slow-growing broiler chickens found by Lemme et al. (2005). Even so, nitrogen excretion values for lay-meat type chickens during the first period of feeding in groups fed the lower-protein basal diet; basal + Met; basal + CP; basal + CP + Met were calculated as 34.9, 33.1, 40.0, $38.8 \mathrm{~g} \mathrm{~N} / \mathrm{bird} / 49$ days, respectively. During the second period of feeding (33 days), nitrogen excretion values in these groups were 55.9, $53.0,60.6$ and $56.9 \mathrm{~g} \mathrm{~N} / \mathrm{bird} / 33$ days, respectively. In total, for a period of 83 days of feeding, $\mathrm{N}$ excretion values were, in the same order, 90.8, 86.1, 100.6 and 95.7 $\mathrm{g} \mathrm{N} / \mathrm{bird}$. The higher protein level in the diet, as compared with the lower, caused an increase in nitrogen excretion, on average by $9.7 \mathrm{~g} \mathrm{~N} / \mathrm{bird}$, but Met supplementation decreased it by $4.8 \mathrm{~g} \mathrm{~N} / \mathrm{bird}$.

Consequently, Met supplementation permitted reduction of nitrogen excretion from chicken production to the environment by 4.7 to $4.9 \mathrm{~g} /$ chicken $/ 83$ days. The reaction of dual-purpose type chickens to Met supplementation to a semi-organic diet containing 0.36 and $0.25 \%$ of total methionine admittedly was statistically not confirmed in this experiment. Nevertheless, the results suggest that synthetic 
Met added to the diet can appreciably limit nitrogen pollution. One could recalculate these figures for larger populations of chickens and compare the result to the admissible $170 \mathrm{~kg} \mathrm{~N} / \mathrm{ha}$ in animal production. For a chicken-house of 4800 birds on an organic farm (EC Regulations 2092/91), nitrogen excretion could be reduced by about $23 \mathrm{~kg}$ during 12 weeks.

\section{CONCLUSIONS}

The results of the experiment with dual-purpose type chickens reared for $>81$ days of age confirmed a better effect on performance of Met supplementation to a semi-organic diet than a higher dietary protein content. The reducing effect of Met on nitrogen pollution of the environment from ecological production is also worth consideration in the discussion on permitting the use of crystalline methionine in organic poultry production.

\section{REFERENCES}

AOAC, 1990. Association of Official Analytical Chemists, Official Methods of Analysis. $15^{\text {th }}$ Edition. Arlington, VA

Carpenter K.J., de Muelenaere H.J.H., 1965. A comparative study of performance on high-protein diets of unbalanced amino acid composition. Proc. Nutr. Soc. 24, 202-209

Havenstein G.B., Ferket P.R., Quereshi M.A., 2003a. Growth, livability, and feed conversion of 1957 versus 2001 broilers when fed representative 1957 and 2001 broiler diets. Poultry Sci. 82, $1500-1508$

Havenstein G.B., Ferket P.R., Quereshi M.A., 2003b. Carcass composition and yield of 1957 versus 2001 broilers when fed representative 1957 and 2001 broiler diets. Poultry Sci. 82, 1509-1518

Lemme A., Damme K., Petri A., 2005. Effect of DL-Methionine on various performance and slaughter characteristics in slowly growing broilers fed according to organic farming recommendations. Arch. Geflügelk. 69, 159-166

Lewis P.D., Perry G.C., Farmer L.J., Patterson R.L.S., 1997. Responses of two genotypes of chicken to diets and stocking densities typical of UK and 'Label Rouge' production systems: I. Performance, behaviour and carcass composition. Meat Sci. 4, 501-516

Mack S., Bercovici D., De Groote G., Leclercq B., Lippens M., Pack M., Schutte J.B., Van Cauwenberghe S., 1999. Ideal amino acid profile and dietary lysine specification for broiler chickens of 20 to 40 days of age. Brit. Poultry Sci. 40, 257-265

Moritz J.S., Parsons A.S., Buchanan N.P., Baker N.J., Jaczynski J., Gekara O.J., Bryan W.B., 2005. Synthetic methionine and feed restriction effects on performance and meat quality of organically reared broiler chickens. J. Appl. Poultry Res. 14, 521-535

NRC, 1994. Nutrient Requirements of Poultry. National Research Council. $9^{\text {th }}$ Edition. National Academy Press. Washington, DC

Quentin M., Bouvarel I., Beri C., Le Bihan-Duval E., Baeza E., Jego Y., Picard M., 2003. Growth, carcass composition and meat quality response to dietary concentrations in fast-, medium- and slow-growing commercial broilers. Anim. Res. 52, 65-77 
Quentin M., Bouvarel I., Picard M., 2005. Effect of crude protein and lysine contents of the diet on growth and body composition of slow-growing commercial broilers from 42 to 77 days of age. Anim. Res. 54, 113-122

Smulikowska S., Rutkowski A. (Editors), 2005. Nutritional Recommendations and Feed Composition Tables for Poultry (in Polish). Publishers: The Kielanowski Institute of Animal Physiology and Nutrition, Jabłonna (Poland) and Polish Branch WPSA

Vieira S.L., Lemme A., Goldenberg D.B., Brugalli I., 2004. Responses of growing broilers to diets with increased sulfur amino acids to lysine ratios at two dietary protein levels. Poultry Sci. 83, 1307-1313

Waldroup P.W., Si J., Fritts C.A., 2001. Relationship of lysine and other essential amino acids on live performance and breast yield in broilers. In: Proceedings of $9^{\text {th }}$ European Symposium on Quality of Poultry Meat (Turkey)

Wethli E., Morris T.R., Shresta T.P., 1975. The effect of feeding high levels of low-quality proteins to growing chickens. Brit. J. Nutr. 34, 363-373

Ziołecki J., Doruchowski W., 1989. The Method for Evaluation of Poultry Carcass (in Polish). Editor: COBRD, Poznań (Poland), pp. 1-30 